\title{
A survey on gender-based violence - The paradox of trust between women and men in South Africa: A missiological scrutiny
}

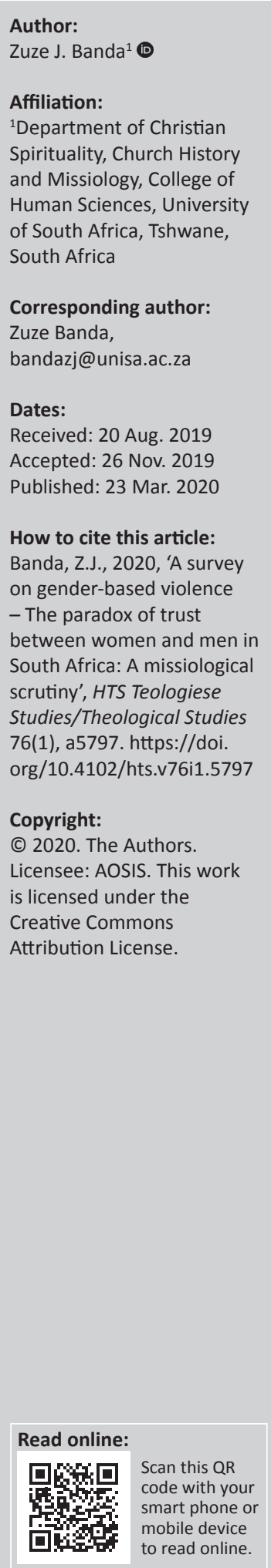

South Africa continues to be plagued by gender-based violence (GBV). Recurring incidents of GBV cram news tabloids, social and electronic media, creating the impression of a country at war with itself. Of great concern is that, at the centre of these killings, men are allegedly the main culprits. This then has unleashed national protest campaigns, one notably, by the name \#menaretrash, led by activists, mostly women, who angrily voice their disquiet against men. As a response, it was followed by another, namely, \#notinmyname, led by those, mostly men, who say, there are many good and proud men who will not allow the image of manhood to be tarnished. At risk is 'trust' which is an important social asset, the demise of which plunges any society into a state of parody. This article then seeks to establish the damage GBV causes in terms of trust, especially of women to men. To do this, a survey was conducted to test levels of trust under different circumstances and in respect of different categories of people and public figures. The findings partly confirm existing surveys elsewhere whilst also making contradicting and worrying revelations. The article tries to reconcile these divergent positions socioculturally and theologically and conclude with proposals towards addressing the scourge of GBV.

Keyword: gender-based violence; abuse; femicide; trust; praxis cycle; patriarchy; religion.

\section{Introduction}

'In South Africa, every 8 hours a woman is killed by an intimate partner' (Makou 2017'1). Makou further argues that the notion that the South African trend of violence against women is 'five times higher than the average in the world' is partly true, as this is an average that unfortunately overlooks the years in which it spiked much higher than that (Makou 2017). These statistics pitted against other popular statistics, including general murders and people dying in political conflict zones, suggest a problem of extreme proportions that apparently runs unbridled and unabated. The results of this onslaught on women can be observed in the indifference shown by women towards overtures or acts of kindness, such as offering a lift and other helping hands. This indicates a broken trust towards men on the part of women.

Gender-based violence (GBV), because of its nature, namely, a crime that happens mostly in private spaces, such as in the home, is certainly disconcerting and baffles even instruments of safety, security and justice. Several authors (including Kroeger \& Nason-Clark 2010; Mazibuko 2015; Nason-Clark 1997 and so on) have written to highlight GBV, especially as perpetrated against women. This article aims, amongst others, to view this problem from an ontological perspective. Hence, some critical questions that intend to help shape the research in that direction are necessary. My primary question is: Is there a growing mistrust between women and men as fellow human beings? This question goes deep even to quiz the biblical motif upon which the creation of humans is based, namely, the objective that man and woman were specifically created for each other (Gn 2). Therefore, it is necessary to probe seriously into the harm GBV does to the tenets of the man-woman relationship. A second critical question is whether GBV does not impinge on the fundamental concept of our being as the imago $D e i^{2}$ (Simango 2012). Moreover, at a secondary level, it is necessary to ask, firstly, whether women and men as preordained models of affection with a subsequent objective to marriage have not lost their initial chemistry of love and affection for each other, especially with man, the proponent of the first eulogy of affection for a woman (Gn 2:233); secondly, to ask what demand these killings place on the ideals of mutual

1.Gopolang Makou, for Africa Check, argues that the notion, 'every eight hours a woman is killed in South Africa', is misleading as that factually refers to femicide by intimate partners.

2.Imago Dei (Latin for 'the image of God'). Simango (2012) argues that the 'image of God' has both moral and relational perspectives. 3.The man said, 'This is now bone of my bones and flesh of my flesh'. 
trust and cooperation, at home, work and in public spaces; and thirdly, to what extent are our human philosophies harmed by this antagonism, especially those which espouse African pride of humanity, including ubuntu, ${ }^{4}$ umoja, ${ }^{5}$ ujamaa $^{6}$ and many of a similar nature. There are several other bothersome questions relating to the increasingly fragile relationship between men and women, which cannot all be covered in this brief article.

\section{Literature review}

In trying to understand the problem under discussion, I have consulted several sources. The first group of sources is short articles. Several were obtained from newspapers (e.g. Pretoria News, cf. Mazibuko 2017a, 2017b), social media and electronic media, ${ }^{7}$ radio and TV talk shows ${ }^{8}$ and reality programmes. These sources are helpful in as far as they highlight the problem and sensitise the general public to issues of GBV. The second group of sources are several books that provide substantive material on the plight and demise of women, many being co-authored, for example, Kroeger and NasanClark (2010), Renzetti, Edleson and Bergen (2011) and Du Toit (ed.) (2000), as well as research theses by Mazibuko (2015) and Stevens (2008), and provide scientific methodologies in approaching this subject. Lastly, the third group are reports and presentations by human rights organisations and advocacy groups, such as Human Rights Watch, Africa (HRW 1995), \#Notinmyname and Women Against Women Abuse (WAWA, http://genderlinks.org.za/programmeweb-menu/women-against-women-abuse-wawa-southafrica). These are mostly surveys conducted to provide factual evidence, as well as public opinions on the problem of GBV. These are a few examples of a problem that has certainly engulfed not only South Africa, but also the whole world (see Kroeger and Nasan-Clark (2010:20-45). The extent of this plight, when read from many of these sources, seemingly beats our human imagination in trying to figure out solutions.

\section{Methodology}

In tackling the problem, I chose to apply the praxis cycle as an analytical tool. The praxis cycle is an adaptable ${ }^{10}$ dynamic research tool that was introduced by Holland and Herriot (1983). According to research designs, the praxis cycle (cf. Kritzinger 2011:4) has four points: insertion, context

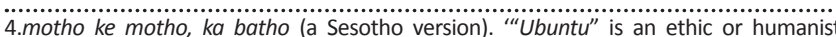
philosophy focusing on people's allegiances and relations with each other (http://www.ubuntu.thiyagaraaj.com/Home/about-ubuntu/ubuntu-philosophymeaning).

5.Umoja the Swahili word for 'unity', 'oneness' (https://www.wordhippo.com/what-is/ the-meaning-of/swahili-word-0141897791833157c7b1df80701ee4ec010a268a.html).

6.Ujamaa. (Noun) An ideology of cooperation and collective advancement that formed the basis of socio-economic policies in Tanzania in the 1960s (https://www. definitions.net/definition/ujamaa)

7.For example, Eye Witness News, viewed 29 June 2018, from http://ewn.co.za/Searc hResultsPage?searchTerm=femicide.

8.For example, SABC Digital News, viewed 29 June 2019, from https://www.youtube. com/watch?v=JY_NQbcriQE.

9.For example, DSTV Channel 157 series, i.a., 'Ufelani?' an investigative show that enacts cases of femicide (cf. Episode of $11 / 11 / 2018$ ) and 'Ukuthula Noxolo', a show on reconciliation initiatives (cf. Episode of 07/04/2019).

10.See Karecki (2000) and Kritzinger (2010) for adapted models of the praxis cycle.

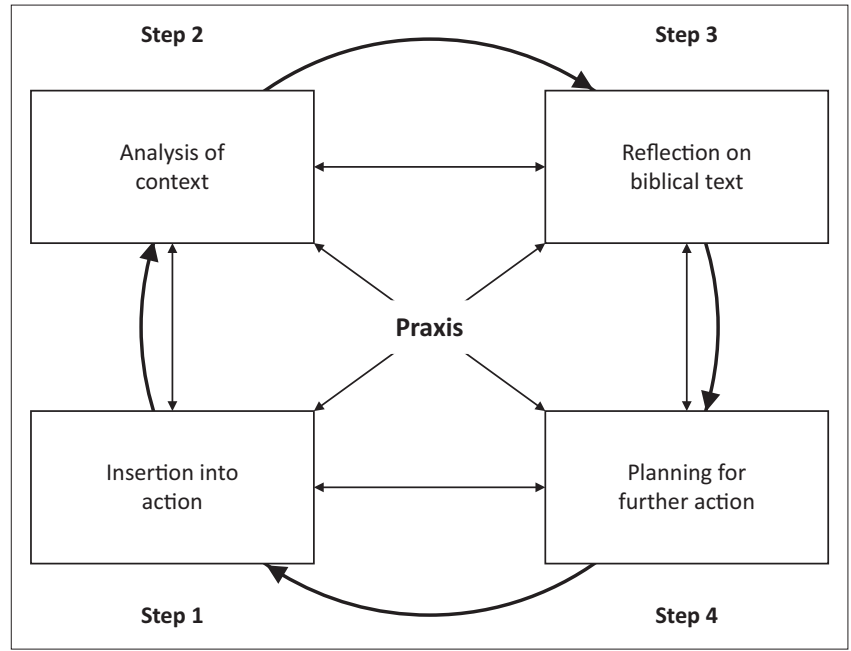

Source: Adapted from Kritzinger, J.N.J., 2011, 'MTHMS1-5_2011_TL_101_0_B', Unpublished Tutorial Letter for Structured MTh (Missiology), Unisa, Pretoria, $\bar{p} .4$

FIGURE 1: Praxis cycle (Study Guide MTHMS15/101/2011, only study guide for M.Th [Missiology] at University of South Africa: Pretoria).

analysis, theological interpretation and planning for action. Under insertion, 11 I discuss my point of entry into and motivation for researching the problem of GBV. I thereafter present an analysis of the context of GBV, followed by theological interpretation using relevant theological tools. I then, finally, present proposals emanating from the discussions of the three other points of the cycle. The four points are interactive and do not necessarily follow a cyclic order (see Figure 1). To further problematise and contextualise this study on GBV, I have conducted a brief public survey, here referred to as a 'trust survey'. This survey, discussed in detail below, has its purpose to verify certain assumptions and perceptions on trust or lack thereof with regard to women in relation to men.

\section{Insertion:12 A cause for concern Apparent silence of church and theology on gender-based violence}

My observation as a theologian and pastor is that the outcry from certain quarters of the society claims that the church is watching helplessly as women suffer the indignity of abuse. Many writings in South Africa on this subject come from other disciplines of human sciences, including sociology (cf. Mazibuko 2015) and psychology (cf. Stevens 2008). Here and there, though, there have been theological responses to the outcry, for instance, the conference which was held by the Research Institute for Theology and Religion whose proceedings were published in a volume (see Du Toit [ed.] 2000). It should be said that this is a far cry in relation to a pandemic that has certainly engulfed the society. From a pastoral point of view, the church is certainly involved, sadly, more from the point of burial of the victims of GBV than from remedial interventions. It may also be asked: What is the message of pastors to the bereaved in these recurring incidents of femicide? Are we just part of the 'undertakers' who only

11.Also known as 'incarnation', after the act of Jesus Christ who became a human being in order to be subjected to human experiences.

12.Insertion often encompasses elements of research such as 'background', 'motivation' or 'reason' for the study. 
show up when the damage is done? Or, should not we be featuring in the prevention and in the fighting of this scourge? Mazibuko (2017), rightly, is critical of the church's apparent silence.

My insertion, though, is not only to appease critics of the apparent status quo but also is derived from a genuine concern and need to add a voice to the actions that are already happening in the church and the academia. In addition, this study hopes to provide, or in the least, propose tools women and men, or peacemaker agencies of GBV can employ to fight this scourge.

\section{Women and trust in personal and public spaces}

The harassment, abuse and killings of women do not only send harrowing news to the public but also do incidentally create responses, as well as form attitudes towards men, when they are in intimate and public spaces. These attitudes inadvertently get seated consciously or subconsciously in the minds of women and inform their responses in their day-to-day encounters. It is no wonder that one of the extreme reactions to women abuse came in the form of the \#Menaretrash movement. As part of my problem statement, the question is the extent to which these hurt feelings affect or have affected the 'normal' menwomen relationships that are important for family, courtship and marital relationships, on the one hand, and for working, sporting and other business relationships on the other hand. My assumptions at the inception of this study were the following: as a consequence of GBV, women's trust of men is at their lowest; women-men relations are tense and suspicious, and that any action or behaviour at work and in public spaces cannot escape the uncomfortable scrutiny of either decency or discourtesy, by observers and especially, women. To test these perceptions, I conducted a public survey.

\section{A public trust survey on gender-based violence}

The nature of the survey was that it would be closed-ended using a questionnaire. My target population was residents in townships north of Pretoria, especially Ga-Rankuwa, Mabopane and Soshanguve. The other target group would be members of WhatsApp groups, which, by observation, would be residents of townships in Johannesburg, Ekurhuleni and Emfuleni and only a few from adjacent suburbs. By the manner of distribution, most, if not all, respondents would be classified as Africans. The distribution of questionnaires did not discriminate participants according to gender, age, marital status and education. Respondents were not required to reveal their religious affiliation, names or any form of personal identity. Hence, the design of the questionnaires was such that the results could not be traced back to their participants.

The design of the questionnaire was to reveal their gender, age, marital status and level of education (questions A1-4); secondly, to reveal whether, on the one hand, they have been victims of violence by a member of another sex category (question A5), and if so, by which of the following persons: parent, sibling, boyfriend or girlfriend, neighbour, teacher, pastor or priest, police, stranger or other person to be specified (question A6), and/or whether they themselves were perpetrators, and to what extent (i.e. never, very rarely, sometimes, often or always) (question A7). I intended question $\mathrm{A} 8$ to be the crux of the questionnaire. It required the respondents to say how much they trust men based on their knowledge of current news of violence carried out by men (irrespective of their age) against women. They were to indicate their levels of trust, on a scale of 1 to 10 , with 1 being the lowest and 10 being the highest.

I also introduced section B to the questionnaire, which was intended to validate and qualify their feelings towards men based on their levels of trust. Most of the questions in this section were modelled on the Likert scale. ${ }^{13}$ Question B1 was to establish if the respondent could leave (1) a daughter who is a minor ( 17 years and below $)^{14}$ and (2) a close relative adult female in the care of an adult male stranger. Question B2 further determines the 'trust' factor in 'personal' spaces (question B2) by asking whether the respondent would be willing to offer a male stranger a lift in her or his (respondent's) car, and further in 'deserted' spaces, such as a bus stop or empty street (question B3a), 'confined' spaces, such as a lift (question B3b), and an even riskier confined space, such as an ATM kiosk (question B3c) where prospects of 'trust' are predictably lower. The last set of questions probing 'trust' were moved away from 'spaces' as risky factors to investigate the trust factor on two familiar and supposedly 'trusted' public figures, by virtue of their professions or calling. The one being a medical doctor, by asking whether the respondent would undress (question B3d) - which is within the 'norm' of the practice - when asked to do so by the medical practitioner. The other being, a pastor, priest or ordained religious leader, by asking the respondent if she or he would meet this professional alone - who, in the codes of conduct of major accepted religious institutions, are regarded as guardians of moral behaviour and generally command public respect - in his consultation room (question B3e).

\section{Findings and context analysis}

The survey yielded interesting results. Firstly, let me discuss the raw personal data and their implications.

The total number of responses was 42 of which three (only 7\%) were from the WhatsApp group. Of these, the majority were women $27(64 \%)$, which suggests that the observations and feelings of women in this survey would be significant, that is, neither muted nor suppressed. A second important consideration was the age of participants. Primarily, participation was limited to the minimum permissible age of an adult in South Africa, which is 18 years.

13.The Likert scale is a five- or seven-point scale that offers a range of answer options from one extreme attitude to another like 'extremely likely' to 'not at all likely'. Typically, they include a moderate or neutral midpoint (https://www.surveymonkey. com/mp/likert-scale).

14.Close-ended optional answers were provided at the end of each scenario. An open-ended fourth optional space was given, which required the respondent to 'explain briefly'. 
Thereafter, I divided the age groups into tens, for simplicity of group analysis' sake. ${ }^{15}$ The age numbers (in years) were as follows: 19-29: 8 (19\%); 30-39: 7 (17\%); 40-49: 14 (33\%); 50-59: $8(19 \%)$ and 60 and above: $5(12 \%)$. We can deduce from these age statistics that respondents were adults of a 'mature' age (64\% above $39^{16}$ years) probably with many years of experience in interpersonal relationships. The marital status revealed that $19(45 \%)$ were single, 1 ( $2 \%$ ) engaged, $17(40 \%)$ married and $4(10 \%)$ divorced. These figures are important, especially as regards the married group, a category that many researchers have found to be susceptible to violence by intimate partners. ${ }^{17}$ The levels of education would speak to whether respondents could understand the questions asked. The figures were: 1 (4\%) for primary, secondary 9 (33\%) and tertiary 16 (59\%) qualifications. Therefore, with the majority having acquired such high levels of competency in reading and ability to give feedback, it is without doubt that any error of a cognitive nature should considerably be discounted.

Secondly, this study discusses the participants' actual involvement in violence as victims and/or perpetrators of GBV. The figures reveal that only $7(17 \%)$ were victims of violence. Those who indicated they suffered as a result of violence further indicated who committed the violence. As could be expected, in accordance with reported media cases, boyfriends formed a big part of the cases here: $3(43 \%$ of victims). This constitutes $30 \%$ of the overall victims of violence (i.e. 10). An interesting observation is that respondents do not list parents and teachers amongst the perpetrators of violence, which makes sense, because, I assume, most were still children when the new constitutional dispensation of 1994, which prohibits capital punishments by parents and educators, ${ }^{18}$ came into existence. My assumption therefore is that corporal punishment by a parent and a teacher is not regarded as violence by participants.

The other overwhelming figure is the participants' relative silence about having acted violently towards persons of another gender. Only $10(24 \%)$ claim to have committed violence, with the frequency of 4 (10\% of 'very rare') and $1(2 \%)$ of 'sometimes'. Again, from those who are parents, none made a claim of spanking their children, and, if they did, they might not have considered that as violence. Although these comments are important, they should not make us lose focus of our topic of GBV, which intends to establish whether men admit committing violence against women and whether women recognise acts of violence when committed against them. These figures should help us further in the analysis of the statistics at the heart of our trust survey, as portrayed under question A8.

15.This categorisation does not follow any novel age group classification such as working age grouping or population pyramid (which uses denominations of 5) (see https://www.indexmundi.com/south_africa/agestructure.html).

16.In South Africa, 35 years is a cut-off age for a youth person.

17.In this survey, categories that claim to have suffered from violence by intimate partners are two by husbands and three by boyfriends, which are $19 \%$ of the women respondents.

18. Experts in quantitative and close-ended questionnaires decry the disadvantage in such surveys that there is no opportunity of follow-up and in-depth inquiry in the respondents' selected ballot answers.
TABLE 1: Trust scale.

\begin{tabular}{lccc}
\hline Category name & Trust indicator & \multicolumn{2}{c}{ Respondents } \\
\cline { 3 - 4 } & & $\boldsymbol{n}$ & $\mathbf{\%}$ \\
\hline Absolutely distrustful & 01 & 4 & 10 \\
Very distrustful & $02-03$ & 3 & 7 \\
Mildly distrustful & 04 & 6 & 14 \\
Neutral $^{20}$ & 05 & 9 & 21 \\
Mildly trustful $_{\text {Very trustful }}$ & $06-07$ & 9 & 21 \\
Absolutely trustful & $08-09$ & 5 & 12 \\
Undecided or unknown & 10 & 5 & 12 \\
\hline
\end{tabular}

\section{The trust scale}

I have grouped the responses to question A8 according to sense-making categories, ${ }^{19}$ which reads according to the following format, as shown in Table 1.

These figures show that nine (21\%) respondents are neutral, meaning neither trustful nor distrustful to men in terms of violent behaviour. Considering ' 5 ' as the divide, we can certainly say women (including men) invariable trust men 19 $(44 \%)$ as opposed to the $13(31 \%)$ at the opposite end. With this as our vantage point, we will probe further as to whether respondents would hold the same sentiment under specific conditions presented by the survey.

Next, the survey reveals a totally different picture under questions B1a and B1b, which are categories that deal with 'entrusting women of all ages in the care of a male stranger'. Overwhelmingly, respondents would not leave a girl minor $34(81 \%)$, and an adult woman $27(65 \%)$ with such a man. We can deduce that the respondents probably fear for their safety whilst left alone with a stranger. This reading is consistent with my earlier observation, namely, that women increasingly no longer respond 'friendly' to male stranger's greetings, overtures of wanting to help, or even any kind of complement made by male folk.

This lack of trust and fear is exacerbated by factors of acts of crime against women. In South Africa where car hijacking is counted amongst high acts of crime, ${ }^{21}$ giving a lift to a stranger is certainly a high-risk factor.

In the same vein, $29(75 \%)$ respondents, which is a substantial number, understandably, would not give a lift to a male stranger. Therefore, this reinforces the notion that 'trust' as behavioural indictor in GBV is definitely an important matter. The issue of unsafe public spaces in the society, with men as cardinal factors of unsafety, became more apparent with the next set of statistics: under question B3a (at a bus stop or deserted street) $74 \%$ and under question B3b (in a lift) $70 \%$ expressing either avoidance or extreme discomfort.

19.The actual responses per each indicator figure are: $01(4), 02(1), 03(2), 04(6), 05(9)$, 06(3), 07(6), 08(3), 09(2), 10(12), 00 (1).

20.Neutral here means, 'undecided'; factually or emotionally 'unsure'.

21.In a recent report of Statistics South Africa (June 2018), 72.3\% women experienced hijacking with $62.7 \%$ men suffering the same fate. (Statistics South Africa's survey must be viewed against the current population estimate of 57.7 million by mid-2018 (http://www.statssa.gov.za/). 
With these stats as high as that, it is not a surprise that $86 \%$ of respondents would also have a serious problem being left alone with a male stranger at an ATM kiosk. These figures underscore the presupposition that there is a general mistrust of men by society.

In the next set of statistics, respondents expressed their lack of trust for medical practitioners, that is, $56 \%$ and ministers of religion, that is $45 \%$, as follows. These figures are of great concern. To my knowledge, though, sexual abuse by medical practitioners against their patients has not received public prominence, perhaps because of the obscure media in which they are reported 22 ; the same cannot be said of ministers of religion. There are many current news reports about religious leaders across diverse church and religious traditions being accused or standing trial on allegations of sexual offences, including rape, harassment and human trafficking. ${ }^{23}$ This category of stats was designed to determine how society considers persons regarded to uphold high ethical standards of conduct. Medical practitioners and many religious leaders have oversight bodies ${ }^{24}$ which protect the integrity of their practices. A closer look of the statistics under some of the questions raises interesting questions. Women when asked if they would undress during medical examination in a medical doctor's surgery responded as follows: A total of $10 \%$ said, 'Will not undress unless there are people next door'; 38\% said, 'Will undress, but feel uncomfortable and be alert' and only $17 \%$ said, 'Will undress and act normal'. I regard $48 \%$ as either inhibitive or apprehensive to what otherwise could be seen as 'normal' practice'25 in a surgery. The suggestion that such a response could be on account of shyness or embarrassment is discounted by the fact that the survey question is clearly suggestive, namely, that 'safety' is the overbearing concern, with the 'trust' factor as a guiding principle.

The survey posed similar questions raised of medical doctors in respect of religious leaders. Surprisingly, different results were obtained. Women, when asked how they would react if left alone with a pastor, priest or religious leader in their consulting rooms, responded as follows: a total of $12 \%$ said, 'Will prefer to leave or request a "safe space"', 19\% said, 'Will stay, but feel unease and always alert' and 29\% said, 'Will stay and act normal'. In comparison with medical doctors (17\%), religious leaders have a huge benefit of 'trust'.

Perhaps, this explains the 'mystery' of support for the beleaguered pastors who are standing trial for all kinds of abuses or who have been in the media for controversial

22.Some of the recent cases of medical doctors accused or found guilty of sexually abusing patients include Dr Yusuf Dadoo (Kgosana 2018), Dr Steven Levy (Miltz 2017) and Dr Charles Odidi (Gumede 2011)

23.To name but a few, Pastor Timothy Omotoso (ANA 2018), Pastor Abednigo Mongwe (aged 28), is accused of raping a 15-year-old girl (Mkhaliphi 2018); Father Adam O'Connor sexually groomed, molested and raped a teen boy from 1985 to 1989 (Etheridge \& Ngqakamba 2018).

24.In South Africa, there is serious debate as to whether government should establish a regulatory body for religious practice (cf. CRL Commission 2017).

25.Although the survey did not suggest what the nature of the consultation was, it is based on the general assumption that it is typical of the medical practice to ask a patient to undress when necessary for examination. religious practices. ${ }^{26}$ These statistics raise important questions including how public 'trust' is earned and acquired. This matter will be considered further under theological interpretation of the survey results.

\section{Some preliminary conclusions on survey statistics}

In concluding the outcomes of this GBV survey statistics, with regard to some of the sections above, the figures reveal perceptions that can be considered as 'normal' within the context of South Africa. For instance, the fear of operating alone in public (especially deserted) spaces can be confirmed as apparent and relatively high by Statistics South Africa (2018:12). Respondents' perceptions are backed by real incidents of crime, where crime against women in South Africa is still regarded as very high. For instance, in the 2016 and 2017 reported cases, 250 of every 100000 women suffered from violence. Of this figure, $68.5 \%$ were rape cases, thus continuing the embarrassing labelling by several media and institutions that decry South Africa as 'the rape capital of the world', a 'title' that is castigated by Wilkinson (2014) of Africa Check as irresponsible because he says it is not backed by facts. ${ }^{27}$ Another disturbing factor which I suppose reveals internalised oppression and abuse by women is the report according to the survey of Statistics South Africa (2018:9), that says, almost on an equal basis, both women and men believe that it is acceptable for a husband to hit his wife, for the following reasons: (1) when the woman goes without telling the husband (men: $6 \%$, women: 5.2\%), (2) neglect children (men: $7.6 \%$, women: $6.5 \%$ ), (3) argues with him (men: $7.7 \%$, women: $6.8 \%$ ), (4) refuses to have sex (men: 3.1\%, women: $2.6 \%$ ) and (5) burns food (men: $1.3 \%$, women: $1.3 \%$ ). Note that these are huge numbers in the light of South Africa's population. What is also surprising in this survey is the average percentage of white women $(2.6 \%)$ versus that of black African women (2.5\%). These are, according to Statistics South Africa (2018:9), 'unexpected results because most white women live in urban areas where there is greater exposure to human rights issues and liberal thinking'.

It is my considered conclusion that there is a real need for multipronged intervention programmes if GBV against women has to be reduced drastically. We can only assume that there is probably a rationale that feeds into the picture that is painted by these statistics. In the next section, as we do a theological interpretation of the problems discussed above, we will probably arrive at some clues that can be useful in the concluding section of this study.

\section{Theological interpretation}

\section{Perspectives on 'trust': From sociocultural to theological vantage points}

Trust is a behavioural disposition in human-to-human encounters. It may be naive to presume that people's behaviour can be understood only as faith or religiously

26.'Rape pastor'; 'Snake pastor'; 'Doom pastor', 'Grass/petrol pastor', 'Homophobic pastor'; 'Scam pastor' (see Banda 2019; Kgatle 2017).

27.See also Khan (2014) who places South Africa as No. 1 in the world on incidents of rape. 
ordered behaviour, for instance, in the doctrines of humankind, relationships of people are premised as given in God's creation of humans, a subject I will discuss herein later. Notwithstanding, though, psychology experiments have been conducted to determine the trust factor under various circumstances. Several authors (in Curtis 2011) treat these views from political (p. 27ff.), medical (p. 75ff.), educational (p. 117ff.) and other spheres of interaction (cf. Marková \& Gillespie 2008). Hence, Liu (in Marková \& Gillespie 2008:52) sees trust as falling under two mutually exclusive, broad models, namely, psychological ('which individualizes trust as a mental state of the individual') and sociological, which 'considers trust as a type of taken-for-granted social phenomenon'. Note therefore that Liu excludes a theological viewpoint of trust.

\section{Understanding 'trust'}

John Locke cited by Hollis (1998:1) regards trust as 'the bond of society', a necessary element in 'our dealings with friends and enemies, neighbours and strangers ... whether in homes, streets, markets, seats of government or other arenas of civil society'. Hence Marková, Linell and Gillespie (2008:3) view trust as 'a relational concept'. Flowing from this understanding, several authors argue for extended levels of trust, which are inspired by different contexts, for instance, rural versus urban, interpersonal versus intergroup relationships (Sheras, P.L. and Worchel, S. 1979), sociocultural (Liu 2011:53), experience (Küng 2010:1) and so on. A sense is generated that there is 'basic trust' which is innate. This is portrayed as 'normative' and forms part of our 'natural'28 self. From this point of view, Lagerspetz (2015) posits that in human encounters, a natural expectation in a home situation differs from that in a public domain. Human presence, as opposed to objects, creates a sense of 'power' or 'undefinable influence' (Weil, in Lagerspetz 2015) which may 'convey friendliness, embarrassment or hostility' (Winch, in Lagerspetz 2015:148). But for Weil (Lagerspetz 2015:149), the 'sacredness' of expectation in the other person is that 'good, and not evil will be done to him [that is, the one expecting]'. As observed from psychosocial analysts, like in the case of Liu (2008:52), the aspect of religion is less or completely disregarded.

\section{Trust as a theological concept}

Küng (2010) ${ }^{29}$ states that trust begins in a person's foetal state and is a learned experience. He argues that trust builds from infancy as 'basic trust' and through experience finally achieves the state of 'fundamental trust'. He concurs with Erikson (Küng 2010:13) that there are three groups of people, namely, those who trust in life based on religious faith, those who are believers but have no trust in life, human beings nor in themselves and those who trust in life without having a

28.Other authors like Küng (2010) and Marková and Gillespie (2008) question the notion of 'natural trust' and see it rather as a human socialisation.

29. Küng is a renown Roman Catholic philosopher and theologian. Amongst his books is Does God Exist?, which persuasively argues for belief in God in the same manne as for 'Trust in God'. religious faith (Küng 2010:13); (Küng 2010:10) encapsulates trust as faith experience in the intriguing words of Dag Hammarskjöld: ${ }^{30}$

I don't know Who - or what - put the question, I don't know when it was put. I don't even remember answering. But at some moment I did answer Yes to Someone - or Something - and from that hour I was certain that existence is meaningful and that, my life, in self-surrender, had a goal. (p. 10)

I use this quote lavishly to underscore the complexity of trust. To what other authors might call 'natural', 'basic' or 'primal' trust, Küng (2010), using Hammarskjöld, introduces us to mystery of trust as rooted in God. ${ }^{31}$

\section{'Trust' in God: A biblical view}

Strong's Exhaustive Concordance of the Bible has 80 words of 'trust' in seven of its conjugations. A total of 34 of these are in the active or imperative forms, suggesting that trust is a requirement for the human being.

It makes sense thus that the majority of these words have 'God' as an object of trust. Hence, the injunction in Jeremiah 17:5: 'Cursed is the man who trusts in mankind, who makes the flesh his strength and turns his heart from the LORD' puts all other verses about 'trust' into perspective. In this verse, God reprimands Israel not to put trust in human beings or human institutions. If trust in God is an irrefutable point of departure for humankind, it puts our survey that measures the trust of respondents to different categories of fellow humans in a precarious situation. The context of God's admonishment to Israel, though, refers to Israel's defiance of God's instruction not to run to the Egyptian and Assyrian kings to seek military protection against the second Babylonian invasion, as that was futile (Gill 2019). Therefore, it is conceivable that the trust we tested is that which is 'normal', basic or fundamental to human relational coexistence. The biblical view suggests that it is an innate trait of human creation by God. That is, we are in our own selves inadequate, and the propensity is to lean on other persons who do not only complement us, but towards whom we are also mysteriously drawn by a 'force of trust' (Küng 2010:12).

\section{Is 'trust' biblically accorded to 'husbands' transferable to all men?}

As indicated above, sociologists point to the need for humans to relate to each other in trust. However, some religious discourses apply this trust to certain categories of human beings. In relation to our topic, I will limit this 'prescribed' trust to all men in general, and specifically to 'husbands' and 'pastors' (otherwise put, religious leaders). The fact of trust in a 'husband' falls within a very wide topic of spousal relationships and in many cultures, especial in Africa, is

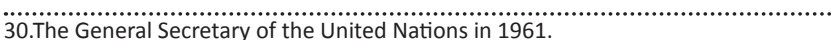
31.It must be said that Küng (2010), even as he points to God as the subject of trust does so with a great measure of scepticism, for he wonders about the fate of billions of 'unbelievers' and adherents of other religions (Küng 2010:6-9). 
subsumed under-patriarchy. ${ }^{32}$ Within the many models of patriarchy, there is a Christian or biblical ${ }^{33}$ patriarchy to which I choose to limit the subject of 'trust'. The biblical notion of trust is enshrined in the analogy of 'wife-husband' as is 'church-Christ' in Ephesians 5:22-33. The defining words for the woman in respect of her husband are: submit, head(ship) and saviour, subject to ... in everything, one flesh ... a great mystery and reverence. Each word is loaded to the extent to which each expositor would like to interpret it. In as much as the husband is obligated to 'love' and perform acts of sacrificial love, these words inculcate and assign subordinate roles to women, as well as create a condition of indispensability for men. This biblical condition can be nurtured by cultures where such a form of patriarchy exists, for instance, African patriarchy, which is described in repulsive manner by Kobo $(2016,2018)$.

The analogy of 'church-Christ' cannot be taken lightly, as it is loaded with unquestionable authority. Any resistance to the notion that 'equates' the 'husband' to the 'Christ' for those who understand the authority of scripture, in a literal sense, might be construed as sacrilege, or worse, blasphemy. Hence, in this sense, how can you not trust such a person who stands in the place of Christ in social institutions such as church, marriage or family?

Further arguments in support of 'trust' for men (father) in a Christian community are advanced in the use of the following scriptures: (1) In 1 Peter 3:6, Apostle Peter coaches women to be subject to their husbands, in the same manner Sarah called Abraham her husband 'my lord or master'; (2) Isaiah 4:1 describes seven women out of desperation are prepared to be 'married' to one man. The elevation of the status and of the role of a man as indispensable by these texts has been used by some Christians and churches ${ }^{34}$ to demonstrate how a man should be accorded the space of authority, respect and trust. African communities as Kobo would argue are susceptible to this notion. African men have thus abused this status to exert undue authority over women and thus irrelevantly elicit trust unfairly to their own benefit.

\section{'Trust' in the 'man of God' investigated}

Furthermore, the level of 'trust' accorded to religious leaders has exposed community and church members to unscrupulous practices of the so-called 'man of God', masquerading under other biblical titles, including 'prophet' and 'apostle', amongst others. These religious practitioners claim to have special relationship to God. Pastor Omotoso told his congregants that he was, according to Mbali Ciliza, a 'friend of God ... and receives calls from God ... and was in heaven communicating with God' and enjoys close 'proximity'

32.Patriarchy simply stated refers to 'the rule of the father' and has over the years sociologically developed to include 'social systems' wherein the male person is the
dominant member of a social economic, political and so forth institution or organisation upon which all other members are dependent by coercion, subjugation or own volition (cf. https://www.merriam-webster.com/dictionary/patriarchy).

33.I use 'Christian' and 'biblical' patriarchy mutatis mutandis as they are closely related though not exactly the same.

34.For example, the International Pentecostal Holiness Church (IPHC) espouses polygyny on the basis of Isaiah 4:1. with God (https://youtu.be/uM8_CiKPk6M?list=PLI93u_ pkmkcHCd36inW4ij7RRwopx9nvN). These claims help accentuate a special position 'men of God' occupy in relation to God. Amongst other men who make claims of visiting 'heaven' are televangelists and prophets Uebert Angel ${ }^{35}$ and Shepherd Bushiri. ${ }^{36}$ In one video clip, Angel names several of 'men of God', including pastors Chris, all of whom are televangelists, as worthy of trust and further cautions 'don't oppose men of God' and 'who are you to judge?', he adds. Any opposition or mistrust to these men amounts to opposition and mistrust to God.

In the words of Ciliza and Zondi, Omotoso, before making sexual advances, he would ask the group of girls to join in prayer in his bedroom, and in the case of Ciliza, even place the Bible on her, suggesting that the lot has fallen on her to 'service' the pastor. Many girls were coerced in this manner and they then succumbed to the pastor's 'divine' advances. It was on the strength of their conscience that Ciliza and Zondi questioned these advances and were even brave to lay charges of sexual assault against the pastor. But still, many of the congregants have come in full view of the media in support of the pastor and even stage public demonstrations outside magistrate courts. One of the slogans widely used in defence of these so-called 'men of God' is 'touch not the anointed of God'. ${ }^{37}$ In light of these elevated statuses of these pastors, 'trust' in them is apparently a God-given mandate and an unquestionable privilege they enjoy.

In a similar 'trust' study conducted in the United Sates, the public was asked to give their perception of 20 public figures. The editorial comment noted,

[T] rust in the clergy fell to [an all-time low $]^{38} 37$ percent, making it the eighth-most-trusted profession in the country - ranking below, among others, a few categories of medical professions, teachers, police and just above journalists and building contractors. (Jackson 2019)

The impression derived from this study is the fact that 'nurses', 'medical doctors' and 'pharmacists' at numbers 1-3, respectively, say much of the professions of health sciences in this country. This is in stark contrast to our survey as discussed above. However, I do unnecessarily want to make a comparative study of these two findings (American and ours), because of complex issues of context and methodology used in obtaining these findings. ${ }^{39}$ I merely want us to note how medical practitioners (doctors) fell below religious leaders (pastors) in levels of trust in our study. At this stage, considering all of the above arguments, fact and reason have

35.Televangelist 'prophet' Uebert Angel (https://www.youtube.com/watch?v =AGzoECMg36k).

36.'Prophet' Shepherd Bushiri (https://youtu.be/Jhe79pvrKy4). NB: At least in his case, the visit was in a dream - a very lengthy and detailed dream.

37.The slogan is derived from David's reprimand of his warriors not to harm King Saul as he was God's anointed servant, and that only God might deal with him accordingly (1 Sm 24); see also his hymn, Psalm 105:15.

38.In an accompanying graph, it shows that it is a gradual fall from $67 \%$ in 1985 sliding down to $44 \%$ in 2017 , and now $37 \%$ in 2018 .

39.NB: Surveys are premised on several contextual dynamics that influence behaviour, perceptions and other trust responses. 
convinced us that we need a 'plan for action' which will provide pathways out of this gloomy situation.

\section{Conclusion and plan of action}

We can therefore conclude that our survey reveals an inculcated disposition by women towards men in general, and towards husbands and pastors, in particular. These attitudes are seemingly derived from a perception that says trust is embedded in the authority granted by God, biblically or by means of 'dreams' or by 'privileged visits' by 'men of God' to heaven, or further still, by culturally ingrained patriarchal notions, amongst a myriad of naturally granted state of affairs. There is a 'stranglehold't0 that makes women feel indebted and ideologically dependent, as well as 'conscripted' to their religious leaders. This makes trust in pastors an unquestionable given, such that only a few who have been deeply hurt can mysteriously gather courage to speak out against them. Kobo (2018) is unrelenting in her objection to how women in society, especially church, are subjected to roles that reinforce subservience and complicity to their demise.

Despite the findings on 'trust' between men and women this survey has obtained, academics and Christian activists for justice should continue to be vigilant and unwaveringly confront the social, cultural and religious indoctrinations and socialisations which foment the abuse of women.

This calls for action on several fronts:

- Dealing with and overcoming contradictions: The study reveals that women have to deal with numerous complex contradictions. The divide between trust and mistrust is often blurred by numerous objective and subjective factors that are difficult to disentangle:

- Mesatywa (2014:243) categorically states issues of poverty and dependency on men, generally, subject women unduly to irrational trust. Professionals and support groups should demystify this unqualified trust on menfolk and religious leaders. Trust must be merited in correlation to the figure of Jesus Christ, the epitome of good character and integrity, coupled with the fruit of the Holy Spirit. ${ }^{41}$

- Addressing guilt and self-condemnation: Study has also shown that sociocultural stereotypes and internalised abuse has subjected women to undue self-blame (e.g. burning food). It has often happened that in divorce or breakdown of relationships, women come out overburdened with guilt, blaming themselves for the failed relationship or responsibilities. ${ }^{42}$ This self-condemnation

40. Better still, 'strongholds', as used here, have a sense that even when a person is liberated (saved), longstanding constraints continue to influence the behaviour of the person.

41.Galatians 5:22-23 (NIV). 'But the fruit of the Spirit is love, joy, peace, forbearance, kindness, goodness, faithfulness, gentleness and self-control. Against such things there is no law'.

42.This is unambiguous in the cases of, on the one hand, the mother whose daughter was murdered, 'Ufelani?', and, on the other hand, of women accepting being hit by husbands for wrongdoing, for example, burning food (Statistics South Africa 2018:12). complicates the issues of trust, as trust must not be shrouded by emotional baggage that is not factual or truthful.

- Rebuilding broken trust in public spaces: 'Charity begins at homes', so goes the adage. Acts of kindness and overtures of help can be regarded with less suspicion when respondents have ingrown confidence derived from the immediate environment at home, church and workplace. The call for moral regeneration should move sloganeering to really moving communities of socialisation to being 'doers of the word'.

- Dealing harshly with deception: There is ample proof above that deception, especially by religious leaders, has taken advantage of women's gullibility to trust. Deception is a word that envelopes several acts, including lying, false promises, misleading and many of such acts that disarm people's intuition, perceptiveness and defence mechanisms:

- People must be empowered to acquire a spirit of discernment. The Bible cautions, 'Do not believe every spirit, but test the spirits to see whether they are from God; because many false prophets have gone out into the world' (1 Jn 4:1), and further advices, 'But examine everything carefully; hold fast to that which is good; abstain from every form of evil' (Th 5:21-22). Agents of safety and security, including police, and the judiciary should deal harshly with people who prey on the vulnerable and the unsuspecting victims.

- Reconciliation: Finally, 'broken trust' should also be remedied in the ministry of reconciliation. The Bible underscores this by stating God's initiative to reconcile humans who had become enemies with Him, through Jesus Christ, and subsequently assigning to members of Christian community the ministry of reconciliation with each other (2 Cor 5:18-23). All persons and structures with a common destiny should intentionally labour towards this societal objective, especially between women and men who are the basic units of human existence.

\section{Acknowledgements Competing interests}

The author declares that no competing interests exist.

\section{Author(s) contributions}

I declare that I am the sole author of this research article.

\section{Ethical consideration}

Full Ethical clearance was granted in terms of project research number 2018-CHS-CE-01, Ethical Clearance Number: REC240816-052, University of South Africa in consideration of interviews conducted for the survey. The certificate is available on request.

\section{Funding information}

No funding was received for this research. 


\section{Data availability statement}

Data of the survey are available on request.

\section{Disclaimer}

The views and opinions expressed in this article are those of the author and do not necessarily reflect the official policy or position of any affiliated agency of the author.

\section{References}

ANA, 2018, 'Nigerian sex pastor trial set to start in Port Elizabeth court', The Citizen, 08 October, viewed 16 October 2018, from https://citizen.co.za/news/south-africa/ 2019385/.

Banda, Z.J., 2013, “"Touch the screen!" - Christian television and its influence and challenge to the Church in South Africa', Unpublished research paper presented at the Departmental Research Seminar of the Department of Christian Spirituality, Church History and Missiology, Unisa, 11th September, 2013.

CRL Commission, 2017, Report on commercialisation of religion and the abuse of people's faith systems, The Commission for the Promotion and Protection of the Rights of Cultural, Religious and Linguistic Communities, viewed 11 June 2019,
from http://www.crlcommission.org.za/docs/Final\%20redesigned $\% 20$ for $\% 20$ from http://www.cr

Curtis, B.R., 2011, Psychology of trust, Nova Science Publ. Inc., New York.

Du Toit, C.W. (ed.), 2000, 'Violence, truth and prophetic silence: Religion and the quest for a South African common good', in A compilation of papers presented at the 23rd Symposium of the Research Institute for Theology and Religion (Unisa) held at the University of South Africa (Pretoria) on 03 and 04 June 1999, 2nd edn., RITR (Unisa), Pretoria.

Etheridge, J. \& Ngqakamba, S., 2018, 'Catholic priest 84 apologises after three decades to man who shared sexual abuse story', News24, viewed 16 October 2018, from https://www.news24.com/SouthAfrica/News/.

Gill, J., 2019, 'Jeremiah 17:5', John Gill's Exposition of the Bible (Online Commentary), viewed 26 March 2019, from https://www.biblestudytools.com/commentaries/ gills-exposition-of-the-bible/jeremiah-17-5.html.

Gumede, S., 2011, 'Doctor guilty of sexual assault', Sunday Independent, viewed 13 August 2019, from https://www.iol.co.za/sundayindependent/.

Holland, J. \& Henriot, P., 1983, Social analysis: Linking faith and justice, Maryknoll, Orbis Books, New York.

Hollis, M., 1998, Trust within reason, Cambridge University Press, Cambridge.

Human Rights Watch, Africa (HRW), 1995, Violence against women in South Africa: State response to domestic violence and rape, Human Rights Watch, New York.

Jackson, G.P., 2019, The 7 People Christians trust more than their pastors, viewed 23 March 2019, from https://www.christianitytoday.com/news/2019/january/ gallup-pastor-clergy-trust-professions-poll.html.

Karecki, M., 2000, Intercultural Christian Communication, Unpublished study guide of Missiology for CMM2603, University of South Africa, Pretoria.

Kgatle, M.S., 2017, 'The unusual practices within some Neo-Pentecostal churches in South Africa: Reflections and recommendations', HTS Teologiese Studies/ Theological Studies 73(3), a4656. https://doi.org/10.4102/hts.v73i3.4656

Kgosana, R., 2018, 'Doctor features in sexual assault row', The Citizen, 21 February, viewed 18 August 2019, from https://citizen.co.za/news/.

Khan, E.C., 2014, 'Countries with the most rape cases', Wonderlist.com, viewed 13 August 2019, from https://www.wonderslist.com/countries-with-the-most-rapecases/.

Kobo, F., 2016, 'Umfazi akangeni ebuhlanti emzini': A womanist dialogue with Black Theology of Liberation in the 21st century', HTS Teologiese Studies/Theological Studies 72(1), a3268. https://doi.org/10.4102/hts.v72i1.3268
Kobo, F.A., 2018, 'A womanist exposition of pseudo-spirituality and the cry of an oppressed African woman', HTS Teologiese Studies/Theological Studies 74(1), 4896. https://doi.org/10.4102/hts.v72i1.3268

Kritzinger, J.N.J., 2010, Integrated theological praxis: Capstone module, the only Study Guide for BTH3720, Unisa Press, Pretoria.

Kritzinger, J.N.J., 2011, 'MTHMS1-5_2011_TL_101_0_B', Unpublished Tutorial Letter for Structured MTh (Missiology), Unisa, Pretoria, p. 4.

Kroeger, C.C. \& Nason-Clark, N., 2010, No place for abuse: Biblical and practical resources to counteract domestic violence, rev. edn., InterVarsity Press, Downers Grove, IL.

Küng, H., 2010, What I believe, transl. J. Bowden, Continuum International Publ. Group, London.

Lagerspetz, O., 2015, Trust, ethics and human reason, Bloomsbury Publishing Plc, London.

Liu, Li, 2008, 'Filial Piety, Guanxi, Loyalty, and Money: Trust in China' in I. Marková \& A. Gillespie (eds.), Trust and distrust, Information Age Publishing, Inc., Charlotte, NC.

Makou, G., 2017, 'Femicide in South Africa: 3 numbers about the murdering of women investigated', Africa Check, 13 July 2017, viewed 17 February 2018, from https://africacheck.org/reports/femicide-sa-3-numbers-murdering-womeninvestigated/.

Marková, I. \& Gillespie, A., 2008, Trust and distrust: sociocultural perspectives, Information Age Publishing, Inc., Charlotte, NC.

Markova, I., Linell, P. \& Gillespie, A., 2008 'Trust and Distrust in Society' in M. Ivana \& G. Alex (eds.), Trust and distrust: Sociocultural perspectives, Information Age Publishing, Charlotte, NC.

Mazibuko, N.C., 2015, 'Women's narratives on domestic violence: A study in Mamelodi, South Africa', a Doctoral thesis, Unisa, Pretoria.

Mazibuko, N.C., 2017a, 'How to beat women abuse - Something must be done, and it starts with each of us', PressReader, 01 August, viewed 27 June 2018, from https://www.pressreader.com/south-africa/pretoria-news/20170801 /281878708452517.

Mazibuko, N.C., 2017b, 'Checkmating the mate: Power relations and domestic violence in a South African township', South African Review of Sociology 48(2), 18-31. https://doi.org/10.1080/21528586.2016.1219967

Mesatywa, N.J., 2014, 'Validating the evidence of violence in partner relationships with regard to Xhosa African women', Social Work 50(2), 235-257. https://doi. org/10.15270/50-2-397

Miltz, N., 2017, 'Johannesburg doctor guilty of unprofessional conduct', South African Jewish Report, 14 September, viewed 13 August 2017, from https://www.sajr.co. za/news-and-articles/2017/09/14/johannesburg-doctor-guilty-of-sexuallyza/news-and-article
abusing-patients.

Mkhaliphi, M., 2018, 'Court postpones rape case against Mpumalanga pastor', SABC News, 11 October, viewed 16 October 2018, from http://www.sabcnews.com/ sabcnews/.

Nason-Clark, N., 1997, The battered wife: how Christians confront family violence, Westminster John Knox Press, Louisville, KY.

Renzetti, C.M., Edleson, J.L. \& Edleson, R.K. (ed.), 2011, Sourcebook on violence against women, Sage, Los Angeles, CA.

Sheras, P.L. and Worchel, S., 1979, Clinical psychology: a social psychological approach, Van Nostrand Reinhold Co., New York.

Simango, D., 2012, 'The meaning of the Imago Dei (Gen 1:26-27) in Genesis 1-11', Old Testament Essays 25(3), 638-656, viewed 13 August 2019, from http://www. scielo.org.za/scielo.php?script=sci_arttext\&pid=S1010-99192012000300012\&lng scielo.org.za/scie
=en\&tIng=en.

Statistics South Africa, 2018, 'Crime against women in SA', Report No. 03-40-05 (June), viewed 16 October 2018, from http://www.statssa.gov.za/publications/Report03-40-05June2018.pdf.

Stevens, G.R., 2008, Men and meanings of murder: Discourses and power in narratives of male homicide in South Africa, University of South Africa, Pretoria, viewed 29 June 2018, from http://hdl.handle.net/10500/2014.

Wilkinson, K., 2014, 'Why it's wrong to call South Africa - Or any country - The world's "rape capital"', Africa Check, 28 January, viewed 15 August 2019, from https://africacheck.org/reports/. 